\title{
IdeAs
}

Idées d'Amériques

13 | 2019

La photographie documentaire contemporaine dans les Amériques

\section{A fotografia documental contemporânea nas Américas}

\section{Marion Gautreau e Jean Kempf}

Tradutor. Lucilia Wuillaume

\section{OpenEdition}

\section{Journals}

\section{Edição electrónica}

URL: http://journals.openedition.org/ideas/5547

DOI: 10.4000/ideas.5547

ISSN: 1950-5701

\section{Editora}

Institut des Amériques

Refêrencia eletrónica

Marion Gautreau e Jean Kempf, «A fotografia documental contemporânea nas Américas », IdeAs [Online], 13 | 2019, posto online no dia 01 março 2019, consultado o 24 setembro 2020. URL : http:// journals.openedition.org/ideas/5547 ; DOI : https://doi.org/10.4000/ideas.5547

Este documento foi criado de forma automática no dia 24 setembro 2020.

\section{(c) (i) $(9)$}

IdeAs - Idées d'Amériques est mis à disposition selon les termes de la licence Creative Commons Attribution - Pas d'Utilisation Commerciale - Pas de Modification 4.0 International. 


\title{
A fotografia documental contemporânea nas Américas
}

\author{
Marion Gautreau e Jean Kempf \\ Tradução : Lucilia Wuillaume
}

1 Tornou-se banal afirmar, ainda que continue sendo necessário repeti-lo, que os vínculos entre a fotografia e o mundo real têm uma natureza específica, decorrente da forma pela qual a imagem é produzida. E é essa particularidade que, rapidamente, a transformou em ferramenta de revelação e de conhecimento do mundo. $O$ que foi, pouco a pouco, definido como "documentário" (concordamos, de forma geral, em situar o aparecimento desse termo nos anos 1920-1930) ancora-se nessa modalidade da imagem fotográfica. Trata-se de utilizar a fotografia, não como uma forma de expressão, mais, inversamente, de exploração. No entanto, ainda que seja aparentemente simples, essa oposição é bem mais didática do que real - não há nenhuma fronteira definida entre as duas áreas. Mas, ainda que existam várias formas de usar a fotografia em seu vínculo com o "real" - de qualquer tipo que seja, familiar, científica, jornalística, de indentidade ou policial - o documentário tem uma natureza diferente. Certamente, ele aproxima-se do fotojornalismo, ou até da fotografia de imprensa, tanto no que diz respeito aos temas abordados, quando, às vezes, no que diz respeito à sua plasticidade. No entanto, é preciso diferenciá-los. 0 documentário não se define, nem por seu estilo, como propôs Olivier Lugon em uma declaração histórica (Lugon O., 2001), nem por seu tema, o extraordinário, como descreveu Stuart Franklin (Franklin S., 2016: 9). Suas características são, por um lado, uma afirmação, uma intenção, uma posição do autor e, por outro lado, uma relação entre o fotógrafo e o sujeito, que implica uma duração (ainda que as temporalidades possam ser muito variáveis, de alquns dias a alguns anos, ou até décadas). Essas duas modalidades implicam também dar uma atenção específica à forma pela qual o documentário será divulgado: formas apropriadas à narração complexa e extremo cuidado do/da fotógrafo/a com o uso que dela será feito. Esse conjunto de exigências resume-se pela palavra «exigência». 
2 Rebeca Monroy Nasr, historiadora da fotografia mexicana há trinta anos e fotógrafa no início de sua carreira, propõe, na introduçao de sua última obra, diferenciar fotojornalismo e fotografia documental, duas práticas cujo objetivo comum é o de informar, mas que possuem modos de realização e usos extremamente diferentes:

A diferença entre a fotografia documental e o fotojornalismo estabelece-se a partir do uso social da imagem e da intenção pela qual o fotógrafo registra essa imagem. Nos considerávamos fotógrafos documentais, pois capturávamos um evento sem certeza de poder vender ou publicar o material. Trabalhávamos com o desejo de legar um depoimento visual do momento, ainda que ele ficasse adormecido em nossos arquivos pessoais; esperávamos a possibilidade de publicar ou, até, expor essas fotos em um espaço público posteriormente. (Monroy Nasr R., $2017: 21)^{1}$.

Desde as grandes operações fotográficas que documentaram as expedições no oeste dos Estados Unidos (surveys) no século xIx, às pesquisas urbanas sobre as más acomodações, a imigração e o trabalho infantil no fim do século (Jacob Riis et Lewis Hine par exemple), até as imagens, finalmente, da Farm Security Administration nos anos 1930, o processo documentário já gozava de um longo passado quando foi retomado e utilizado, a partir dos anos 1920 e, depois, principalmente nas décadas de de 1930 a 1960, pela imprensa ilustrada sob a forma de ensaio fotográfico - photo essay em inglês, fotoensayo em espanhol (Chouard G. et al., 2014). Esse termo, que podemos traduzir por "essai photographique", mas que é muito pouco utilizado em francês, retoma os códigos do ensaio literário: propor uma reflexão estruturada em torno de uma questão claramente delimitada para suscitar a conscientização e lançar, eventualmente, um debate em torno da questão. Foi nesse âmbito que alguns fotojornalistas adoptaram em sua profissão a prática da segunda câmera ("doble cámara", en espanhol). O primeiro aparelho é usado para fazer fotos destinadas aos jornais e aos sites de informação na internet; ele produz imagens que permitem ver, da melhor forma possível, o conteúdo informativo sobre a situação. Quanto ao segundo aparelho, ele é usado para produzir imagens que vão se inserir nas séries fotográficas, pensadas como tais, e realizadas no longo prazo. É o caso, por exemplo, de Fernando Brito, fotojornalista mexicano do Estado de Sinaloa, que denuncia, por meio de seu trabalho documentário, as violências da guerra do narcotráfico, fortalecendo, assim, uma consciência social intrinsicamente ligada ao documentário.

4 A dominação dos modelos norte-americanos no universo fotográfico a partir de, pelo menos, o fim da Segunda Guerra Mundial é um fato, não somente no âmbito da fotografia artística (ou plástica). No entanto, subsiste, inclusive em nosso mundo globalizado das imagens, cuturas específicas - locais - que atraem, ou simplesmente produzem, formas específicas de narrativa visual. A dificuldade e o interesse de pensar o documentário fotográfico em sua integralidade a partir do continente americano, provém das diferenças de temporalidade na evolução dessa prática fotográfica de acordo com as regiões. Aliás, como a história da fotografia foi escrita e divulgada na Europa e nos Estados Unidos e a partir deles, a exumação da história da fotografia documental nos países da América Latina, demanda, algumas vezes, um verdadeiro trabalho de pesquisa arqueológica. Ainda que, evidentemente, essa linhagem exista, apesar da ausência de traçado, poucas narrativas de historiadores descrevem a genealogia do documentário chileno ou brasileiro, enquanto, do lado norte-americano, desde, pelo menos o artigo de Beaumont Newhall de 1938 e, em seguida, a primeira edição de sua história da fotografia (1949), esse gênero foi identificado, descrito, codificado e, em parte, também enquadrado e denominado ${ }^{2}$. 
5 Ademais, não existe, a priori, uma convergência entre as diferentes fases da fotografia de documentário de norte a sul do continente, assim como não existe convergência entre os "diferentes suis" do continente. As técnicas se difundem da mesma forma em toda a América (aparecimento da similigravura, generalização da película flexivel, introdução da cor, passagem à fotografia digital). No entanto, a impulsão dada à fotografia documental por instituições e contextos políticos e sociais, assim como pelas possibilidades de produções, difere sensivelmente, de acordo com os países. As ditaduras do Cone Sul nos anos 1970 e 1980 revelam, ao mesmo tempo, uma necessidade gritante de ensaios fotográficos sobre esse período de repressão e uma impossibilidade material e física de realizá-los ${ }^{3}$. No mesmo período, ao contrário, expande-se no México uma intensa atividade documental que se origina no fotojornalismo, em particular, através dos jornais Unomásuno e La Jornada, do qual, no entanto, os fotógrafos vão pouco a pouco se emancipando, optando pelo tempo longo.

6 Por essa razão, escolhemos pedir a especialistas da fotografia e das culturas das Américas que refletissem, em vez da convergência, sobre práticas documentárias específicas, evidenciando a diversidade, a riqueza e a complexidade.

7 Esse número sobre as práticas documentais nas Américas (sem buscar, evidentemente, qualquer exaustividade) organiza-se, no entanto, em torno de três modalidades encontradas em graus diversos em muitos projetos documentais: a referência científica ou, ao contrário, ideológica; a forma artística como acesso às complexidades do real; e, finalmente, o uso do documentário como ferramenta de afirmação de uma identidade ou de uma reconquista de memória.

8 Aliando a observação de longo prazo com a narração, o documentário usa séries, naturalmente et abundantemente, de acordo com formas mais ou menos restritas, mas que sempre dilatam a dimensão temporal para compreender seu sentido no processo de transformação. É o caso do meticuloso trabalho de inventário de Camilo José Vergara, um fotógrafo chileno que trabalhou nos Estados Unidos, onde compilou um metódico arquivo urbanístico de guetos negros. Nele, Philippe Bazin (ele próprio fotógrafo) vê uma máquina de guerra no sentido deleuziano "um meio de fazer sair [o gueto] da rigidez no qual o ultraliberalismo violento o encerra há décadas".

9 Tão envolvidos quanto, mas quase nos antípodos da forma, as imagens que criou o suisso Jean-Claude Wicky, entre 1984 e 2001, das minas bolivianas são um exemplo, ao mesmo tempo da fotografia humanista clássica - que lembra, com corpos representados em ricas ampliações em preto e branco, as imagens de W. Eugene Smith - e da observação participativa. Baptiste Lavat nos apresenta, com o trabalho pouco conhecido na França de Jean-Claude Wicky, a experiência de muitos documentaristas no quotidiano: o compartilhamento de vidas que não são mais exatamente a de seus sujeitos sem, no entanto, jamais ser completamente a deles, uma situação intermediária difícil pela qual também passam etnólogos, ou, até mesmo, sociólogos.

Dessa forma, um contraste brutal espera o leitor que seguiria a ordem do sumário para descobrir, em seguida, o espetáculo da catástrofe, que é a forma pela qual Danièle Méaux nomeia as imagens das "ruinas de Detroit" de Yves Marchand e Romain Meffre, e o trabalho sofisticado e ambiguo de Joel Sternfeld sobre a High Line de New York. Os vestígios de um passado industrial poderoso suscitam, hoje, um grande interesse pelo, segundo a bela expressão cunhada pela autora, "neopitoresco decrépito", que explora a fotografia pós-moderna; apesar das imagens que estimulam a imaginação dos locais e propõem "uma paisagem em formação", Joel Sternfeld, tendo, inclusive, documentado a 
transformação paisagística do passado industrial, participa da reapropriação chic por classes sociais privilegiadas dos antigos espaços de trabalho e de produção, transformados em áreas de lazer.

11 Essa dificuldade de dizer a brutalidade e a exclusão gerada pela cidade moderna, e de forma mais geral, de expressar o real verdadeiro (em seu aspecto mais cru), é analizada por Gwen Cressman, que escolheu, para isso, comparar duas obras fotográficas muito diferentes, a de Martha Rosler e a de Jeff Wall, que compartilham, no entanto, a mesma desconfiança diante da possibilidade de um acesso simples e direto ao real pela fotografia. Plásticas e conceituais, suas fotografias não cessam de interrogar esse desejo de ver, e a resistência que tem o mundo a se deixar compreender.

Muito mais concreta, a terceira parte dessa entrega propõe três percursos diferentes que aliam o depoimento sobre uma ou mais realidades sociais, culturais ou históricas e a tentativa de desconstrução dos estereótipos através, não somente, da fabricação de imagens, mais também da integração a conjuntos discursivos, a disposições específicas. Morgana Herrera apresenta o trabalho de Musuk Nolte, um fotógrafo peruano que, através de séries em preto e branco, se coloca a contracorrente das representações exóticas do espaço amazônico. Graças à escolha dos temas (mais urbanos do que rurais) e ao tratamento das pessoas fotografadas (em seu quotidiano e as restrições ligadas às suas condições de vida), ele oferece um lugar não etnográfico aos habitantes da Amazônia peruana, no cenário visual internacional. Maude Oswald, quanto a ela, mostra como um inventário de signos funcionais (as marcas da defesa civil nos prédios abandonados após o furacão Katrina) torna-se, na internet, uma ferramenta de construção memorial a posteriori, significando, assim, a ação "de retorno" dos fotógrafos ao real, sob a forma de uma reapropriação. Essa reapropriação está no cerne do projeto que se propõe estudar Aurélie Journée: o de uma fotografia ameríndia, cujos retratos tentam combinar herança ancestral e modernidade que pode fazer advir uma palavra mais liberta, principalmente das mulhers autóctones.

Podemos ver que o percurso proposto é necessariamente parcial, sem deixar de dar conta das sutils diferenças situadas no cerne da preocupação que perpassa o documentário: a da emancipação.

\section{BIBLIOGRAFIA}

Chouard, Géraldine, Kempf, Jean et Brunet, François, « La photographie "documentaire" américaine : nouvelles approches ", Transatlantica, vol. 2, 2014, http://journals.openedition.org/ transatlantica/7245, page consultée le 23 février 2019.

Franklin, Stuart, The Documentary Impulse, Londres, Phaidon, 2016.

Lugon, Olivier, Le style documentaire : d'August Sander à Walker Evans, 1920-1945, Paris, Macula, 2001. Meiselas, Susan (dir.), Chile from within, New York ; Londres, W.W. Norton \& Company, 1990. 
Monroy Nasr, Rebeca, Con el deseo en la piel. Un episodio de la fotografía documental a fines del siglo xx, Mexico, UAM-Xochimilco, 2017.

Newhall, Beaumont, « Documentary Approach to Photography », Parnassus, vol. 10, n 3, 1938, p. 2-6 [accessible sur JSTOR, http://www.jstor.org/stable/771747].

Newhall, Beaumont, The History of Photography from 1839 to the Present Day, New York, Museum of Modern Art, 1949. Traduction française en 1967.

\section{NOTAS}

1. «La diferencia entre fotodocumentalismo y fotoperiodismo se establece a partir del uso social de la imagen y la intención con la que el fotógrafo toma esta imagen. Nos considerábamos fotógrafos documentales aquellos que captábamos el acontecimiento sin tener la certeza clara de la venta o la publicación del material. Trabajábamos con el deseo de dejar un testimonio visual del momento aunque éste solo se integrara a nuestro acervo personal, con la posibilidad de publicar posteriormente para realizar alguna exposición o edición de las imágenes en algún espacio público. »

2. Podemos, no entanto, citar nomes de historiadores latino-americanos da fotografia que, atualmente, reconstruem essas narrativas pouco a pouco: Cora Gamarnik na Argentina, Boris Kossoy e Ana María Mauad no Brasil, Rebeca Monroy Nasr, John Mraz e Alberto del Castillo no México, para citar somente alguns.

3. Consultar, a esse respeito, Meiselas S., 1990.

\section{AUTORES}

\section{MARION GAUTREAU}

Enseignante-chercheuse au département d'études hispaniques et hispano-américaines de l'Université Toulouse-Jean Jaurès. Historienne de la photographie latino-américaine, elle est notamment spécialiste du Mexique. Ses recherches portent essentiellement sur la photographie de presse et la photographie documentaire dans leur articulation avec le récit historique national, aux $\mathrm{xx}^{\mathrm{e}}$ et $\mathrm{xxI}^{\mathrm{e}}$ siècles. Elle a publié un ouvrage sur la photographie de la Révolution mexicaine, De la crónica al ícono: la fotografía de la Revolución Mexicana en la prensa ilustrada capitalina (1910-1940), et travaille actuellement sur le photojournalisme mexicain depuis 1968.

\section{JEAN KEMPF}

Professeur de civilisation des États-Unis à l'Université Lumière-Lyon 2. Il est spécialiste de l'histoire de la photographie américaine au $\mathrm{xx}^{\mathrm{e}}$ siècle. Il a notamment écrit sur la commande institutionnelle, sur les street photographers et sur les pratiques documentaires, et s'intéresse aujourd'hui à la sociologie des milieux photographiques contemporains. Il a participé à l'aventure de L'Amérique des images (Hazan, 2013) et a publié une Histoire culturelle des États-Unis (Belin, 2015). 